\title{
Deep-sea polymetallic nodules as opportunity for future supply with critical raw materials
}

\section{Дълбокоморски полиметални конкреции като възможност за бъдешо снабдяване с критични суровини}

\author{
Valcana Stoyanova ${ }^{1}$, Atanas Hikov ${ }^{2}$, Elitsa Stefanova ${ }^{2}$, Zlatka Milakovska ${ }^{2}$,Tomasz Abramowski, \\ Irena Peytcheva ${ }^{2}$, Silvia Chavdarova ${ }^{2}$, Milen Stavrev ${ }^{2}$ \\ Вълкана Стоянова ${ }^{1}$, Атанас Хиков $^{2}$ Елица Стефанова ${ }^{2}$, Златка Милаковска ${ }^{2}$, \\ Томаш Абрамовски ${ }^{1}$, Ирена Пейчева ${ }^{2}$ Силвия Чавдарова ${ }^{2}$, Милен Ставрев ${ }^{2}$
}

\footnotetext{
${ }^{1}$ Interoceanmetal Joint Organization, 9 Cyryla I Metodego Str., 71541 Szczecin, Poland; E-mail: valcanastoyanova@gmail.com

${ }^{2}$ Geological Institute, Bulgarian Academy of Sciences, Acad. G. Bonchev Str., B1. 24, 1113 Sofia; E-mail: ahikov@geology.bas.bg
}

\begin{abstract}
The renewed importance of polymetallic nodules in the context of forecasted increasing demands for metals are discussed. Based on the Interoceanmetal Joint Organization's (IOM) site-specific data obtained during the exploration activity in the Clarion-Clipperton Fracture Zone, a total of $272.5 \mathrm{Mt}$ of nodules were estimated as economically reasonable for future mining for $\mathrm{Ni}, \mathrm{Cu}, \mathrm{Co}$, and $\mathrm{Mn}$. Additionally, data for $\mathrm{REE}$ and other critical elements in nodules as potential by-products are presented.
\end{abstract}

Keywords: critical raw materials, polymetallic nodules, manganese, REE, Clarion-Clipperton Fracture Zone.

\section{Introduction}

Rapidly increase of interest to explore deep seabed mineral resources (in particular polymetallic nodules) is seen in the last decade although the deep-sea mining is not commercially viable at present. Nowadays, the International Seabed Authority (ISA) has entered into 31 contracts for exploration for deepsea minerals, thus 19 of these contracts are for exploration of polymetallic nodules in the ClarionClipperton Fracture Zone (CCZ), NE Pacific Ocean (17), Central Indian Ocean (1) and Western Pacific Ocean (1) (ISA, 2021). The richest nodule deposits and consequently most exploration claims registered with the ISA are located in the CCZ. A conservative estimate of the dry tonnage of nodules in the $\mathrm{CCZ}$ is $21100 \mathrm{Mt}$ (Hein et al., 2013). These deposits are considered alternatives to depleting land resources of strategic metals such as $\mathrm{Cu}, \mathrm{Ni}, \mathrm{Co}, \mathrm{Pb}, \mathrm{Zn}, \mathrm{Mo}$, $\mathrm{Pt}$, and REE that are required for various industrial purposes (Kuhn et al., 2017). Many of metals found in polymetallic nodules $(\mathrm{Bi}, \mathrm{Co}$, HREE, LREE, $\mathrm{Li}$, PGE, Sr, Ti, W, and V) are defined as critical raw materials for the EU in 2020 (COM(2020) 474).
Mining of polymetallic nodules from the seabed is still in uncertain terms; perhaps the most important barrier is economic. However, the recent research indicates that deposits of polymetallic nodules have the potential to be economically feasible for exploitation in the presence of favorable metal prices, as well as in accordance with the technological improvement of the mining and processing systems (Volkmann et al., 2018; Abramowski et al., 2021a).

This study presents results based on the currently available synthesis of knowledge on the valuation of polymetallic nodule deposits of the Interoceanmetal Joint Organization (IOM). The IOM, an intergovernmental consortium sponsored by governments of six countries (Bulgaria, Cuba, the Czech Republic, Poland, the Russian Federation, and Slovakia), was among the first "pioneer investors", which in 2001 concluded with the ISA a contract for exploration for polymetallic nodules in $75000 \mathrm{~km}^{2}$ seafloor claim area, situated in the eastern part of the CCZ, NE Pacific ocean (Fig. 1). The structure of the IOM investment project in general contains the analysis of the financial flow and technological developments of commercial phases of the project implementation, 


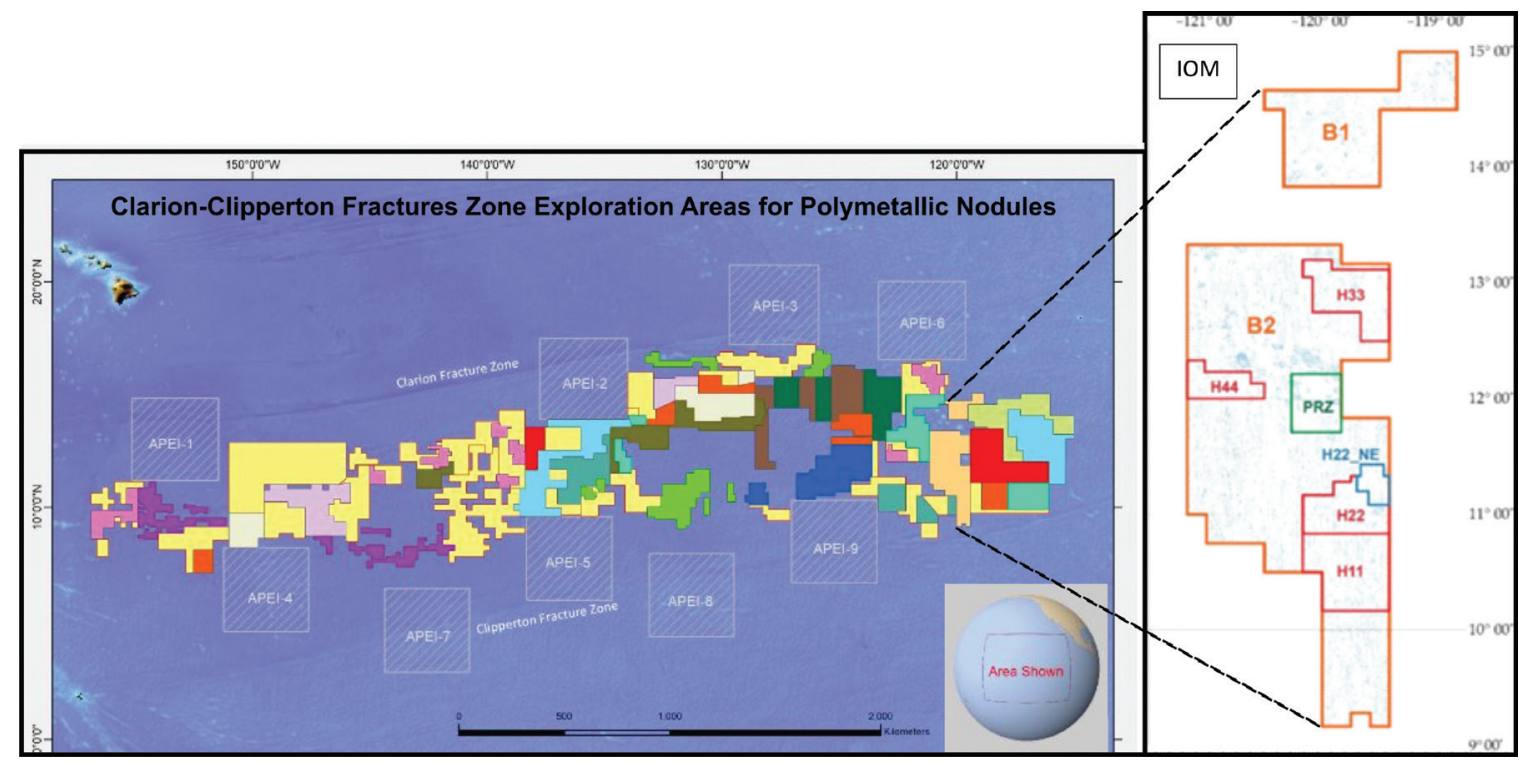

Fig. 1. Map of polymetallic nodules exploration areas in the Clarion-Clipperton Fracture Zone, NE Pacific Ocean (www.isa.org. $\mathrm{jm}$ ); on the right, the IOM exploration area (sectors B1 and B2) with exploration and exploitable blocks, included in the resource estimation (adapted from Abramowski et al., 2021b)

namely, deep-sea mining operations, metallurgical processing, and economic criteria investigations.

\section{Materials and methods}

The source of materials for this paper is based on extensive data and information obtained from more than 25 scientific expeditions and onshore investigation carried out by the IOM in the license area (Dreiseitl, 2016; Abramowski et al, 2021b). The results of this comprehensive research, which included geological documentation, technology of nodule extraction and processing as well as research on the marine environment in the exploration area, were summarized in the IOM Preliminary Economic Assessment Technical Report prepared in 2018 (IOM fund). Resource estimation is based on geostatistical data analysis of nodule samples collected during the above-mentioned expeditions carried out by the IOM.

Geochemical studies of REE in polymetallic nodules at the Geological Institute, BAS started in 2012 (Dimitrova et al., 2014) and continued with the samples from the 2019 Interoceanmetal cruise. The concentration of 58 elements in nodules was determined by LA-ICP-MS (New Wave UP193FX excimer laser combined with a PerkinElmer ELAN DRC-e ICP-MS) at the Geological Institute, BAS. Chemical composition of bulk nodule samples was measured on pressed pellets while the in situ trace element composition was measured on polished sections.

\section{IOM resources summary}

According to the CRIRSCO (Committee for Mineral Reserves International Reporting Standards) directives, the resources of polymetallic nodules in the IOM license area can be categorized as ,,inferred" in B1 and B2 exploration sectors, as ,indicated" in H11 and H22 exploration blocks, and as measured in the H22_NE exploitable block (Fig. 1).

The current status of mineral resource estimate of wet polymetallic nodules in the entire IOM exploration area and its first generation minable blocks/sites is shown in Table 1. Within the whole exploration area and blocks, the accuracy of nodule resource estimation is high, with the relative (kriging) standard error of the estimate of 3-8\%. The accuracy of $\mathrm{Cu}$, $\mathrm{Co}, \mathrm{Mn}$, and $\mathrm{Ni}$ grade estimates is highly satisfying in areas of any size due to low variability of metal contents, resulting from stable chemical composition of polymetallic nodules. The number of geological samples is statistically important for the purpose of the resource estimation. Therefore, the subject of this economic analysis was primarily focused on the base metals, also for the IOM's purpose of developing metallurgical processing methods. The total resources of the exploration areas and blocks were obtained by a summation of values estimated for basic calculation blocks. The $10 \mathrm{~kg} / \mathrm{m}^{2}$ cut-off abundance in the basic calculation blocks can be considered as economically reasonable, i.e. ensuring high probability of economic benefit from mining operation.

\section{Grades of REE and other trace elements}

In the IOM contract area, the nodule ores contain also other metals of economic importance. The mean contents with the number of determinations presented below included: Mo $(0.061 \%$, $\mathrm{n}=457), \mathrm{Zn}(0.143 \%, \mathrm{n}=520), \mathrm{V}(0.045 \% ; \mathrm{n}=$ 
Table 1. Mineral resource estimate of wet polymetallic nodules in the B1 and B2 sectors of the IOM exploration area

\begin{tabular}{lcccccc}
\hline Mineral resource classification & $\begin{array}{c}\text { Mean abundance } \\
(\text { wet kg/m²) }\end{array}$ & $\mathrm{Mn}(\%)$ & $\mathrm{Ni}(\%)$ & $\mathrm{Cu}(\%)$ & $\mathrm{Co}(\%)$ & $\begin{array}{c}\text { Resources } \\
(\mathrm{Mt}) *\end{array}$ \\
\hline $\begin{array}{l}\text { Measured (H22_NE block) } \\
\text { Measured total }\end{array}$ & 14.6 & 29.19 & 1.31 & 1.25 & 0.18 & 12.2 \\
Indicated (H11 and H22 blocks) & 12.4 & 31.37 & 1.30 & 1.29 & 0.16 & 77.0 \\
Indicated total & & & & & & 77.0 \\
Inferred (B1 sector) & 13.4 & 27.84 & 1.21 & 0.90 & 0.21 & 62.6 \\
Inferred (H33 block) & 12.0 & 32.35 & 1.41 & 1.2 & 0.18 & 21.8 \\
Inferred (H44 block) & 11.5 & 30.71 & 1.32 & 1.19 & 0.19 & 13.6 \\
Inferred (B2 sector other) & 11.6 & 30.90 & 1.32 & 1.21 & 0.18 & 85.3 \\
Inferred total & & & & & & 183.3 \\
Grand total & & & & & & 272.5 \\
\hline
\end{tabular}

*Sector B2 includes exploration blocks H11, H22, H33, and H44 and exploitable block H22 NE

Note: Cut-off abundance $10 \mathrm{~kg} / \mathrm{m}^{2}$ of wet nodules, without volcanoes, outcrops, seabed areas free of nodules, and areas sloped over $7^{\circ}$ (Abramowski et al., 2021a; IOM fund)

$180), \mathrm{Pb}(0.032 \%, \mathrm{n}=517), \mathrm{Sr}(0.067 \% ; \mathrm{n}=284)$, $\mathrm{Ba}(0.211 \% ; \mathrm{n}=279) ; \mathrm{Cr}(0.0014 \% ; \mathrm{n}=91)$, As $(0.007 \% ; \mathrm{n}=256), \mathrm{Ti}(0.37 \%, \mathrm{n}=180), \mathrm{Fe}(5.88 \%$; $\mathrm{n}=531)$ (IOM fund data).

Results of LA-ICP-MS analyses of bulk nodule samples confirm the IOM data for $\mathrm{Mn}, \mathrm{Cu}, \mathrm{Ni}, \mathrm{Co}$, and the elements listed above. Furthermore, data on the presence of REE and other trace elements in the polymetallic nodules were obtained. The concentrations of characteristic elements are as follows (in ppm): $\mathrm{Li}$ (77-177, mean 129.7), Sc (7.7-11.7, mean 9.99), Ga (38-52, mean 44.9), Zr (204-340, mean 272.7), Pd (0.34-0.73, mean 0.58), Cd (8.6-20.8, mean 17.3), In (0.14-0.25, mean 0.21), Sb (35-65, mean 49.3), Te (4.2-8.9, mean 5.9), Hf (3.1-5.3, mean 4.35), W (51-111, mean 75.9), Tl (53-410, mean 232.6), Bi (2.5-7.1, mean 5.1), Th (5.5-15.6, mean 11.05), and $\mathrm{U}(2.6-4.6$, mean 4.1). The $\Sigma \mathrm{REE}$ varies from 339.2 to $719.1 \mathrm{ppm}$ (mean $594.27 \mathrm{ppm}$ ), $\Sigma \mathrm{REY}$ is from 380.8 to $800.8 \mathrm{ppm}$ (mean $664.27 \mathrm{ppm}$ ), and $\Sigma$ HREE is from 47.8 to $105.5 \mathrm{ppm}$ (mean $87.72 \mathrm{ppm}$ ).

Grades of REE in the polymetallic nodules are generally lower than those for the land-based deposits, but in terms of the tonnages they are much greater (Hein et al., 2013). Additionally, relative amount of HREE in the marine deposits is quite high when compared to the land ones: up to $26 \%$ of the total REEs (Halbach, Jahn, 2016). The different REE grades are related to different genetic types of nodules: hydrogenetic type - the highest, diagenetic type - the lowest grades. Geochemical analyses have revealed fractionation of REEs in the marine deposits (Halbach, Jahn, 2016): the $\delta-\mathrm{MnO}_{2}$-phase preferentially carries LREEs, whereas the Fe-oxyhydroxide-phase contains more HREEs.

The REE and other trace elements referred as critical raw materials are potential by-products of the major metal mining (Halbach, Jahn, 2016) as well as elements relevant to metallurgical processing. This explains the growing importance of deepsea polymetallic nodules as a potential source for future supply with critical raw materials.
Acknowledgements: The study is partly financially supported by Bulgarian National Science Fund, project КП-06-H34/6.

\section{References}

Abramowski, T., M. Urbanek, P. Baláž. 2021a. Economic assessment of Polymetallic Nodules Mining Project with updates to present market conditions. - Minerals, 11, 311, 1-21; https://doi. org/10.3390/min11030311.

Abramowski, T., V. Stoyanova, K. Mianowicz, Y. Jerzy-Mostashova. 2021b. Advances on technological and economic factors in the development of the deep-sea polymetallic nodules project of the Interoceanmetal Joint Organization. - Proc. 16th Int. Conf. Open and Underwater Mining of Minerals. Varna, Bulgaria, 81-85.

COM (2020) 474. Critical Raw Materials Resilience: Charting a Path towards Greater Security and Sustainability, European Commission, $23 \mathrm{p}$.

Dimitrova, D., Z. Milakovska, I. Peytcheva, E. Stefanova, V. Stoyanova, T. Abramowski, M. Wälle. 2014. Trace element and REY composition of polymetallic nodules from the Eastern ClarionClipperton Zone (Northern Pacific Ocean) determined by in situ LA-ICP-MS analyses. - C.R. Acad. bulg. Sci., 67, 2, 267-274.

Dreiseitl, I. 2016. Deep-sea exploration for metal reserves - objectives, methods and look into the future. - In: Abramowski, T. (Ed.). Deep-Sea Mining Value Chain: Organization, Technology, Development, Interoceanmetal Joint Organization. Szczecin, Poland, 105-117.

Halbach P., A. Jahn. 2016. Concentrations and metal potentials of REEs in marine polymetallic nodule and Co-rich crust deposits. - In: Abramowski, T. (Ed.). Deep Sea Mining Value Chain: Organization, Technology, Development, Interoceanmetal Joint Organization. Szczecin, Poland, 119-131.

Hein, J., K. Mitzell, A. Koschinsky, T. Conrad. 2013. Deep-ocean mineral deposits as a source of critical metals for high- and greentechnology applications: Comparison with land-based resources. Ore Geol. Rev., 51, 1-14.

ISA (International Seabed Authority). 2021. Exploration Areas: Clarion-Clipperton Fractures Zone; https://www.isa.org.jm/contractors/exploration-areas.

Kuhn T., A. Wegorzewski, C. Rühlemann, C. Vink. 2017. A composition, formation, and occurrence of polymetallic nodules. - In: Sharma, R. (Ed.). Deep-Sea Mining: Resource Potential, Technical and Environmental Considerations. Berlin, Springer Verlag, 23-63; https://doi.org/10.1007/978-3-319-52557-0_2.

Volkmann, S., T. Kuhn, F. Lehnen. 2018. A comprehensive approach for a techno-economic assessment of nodule mining in the deep sea. - Mineral Economics, 31, 319-336; https://doi.org/10.1007/ s13563-018-0143-1. 